\title{
Upaya Perlindungan Hukum Bagi Pasien BPJS Terkait Sistem Rujukan Rumah Sakit di Kota Yogyakarta
}

\author{
Finensia Aulia Kusumastuti ${ }^{1}$, Mukti Fajar ND $^{2}$ \\ 1,2 Program Studi Hukum, Fakultas Hukum, Universitas Muhammadiyah Yogyakarta, Indonesia \\ E-mail: ${ }^{1}$ finesia.aulia.2014@law.umy.ac.id, ${ }^{2}$ muktifajar@umy.ac.id
}

\section{Info Artikel}

Diajukan: 04-08-2020

Direview: 18-08-2020

Direvisi: 24-08-2020

Diterima: 25-08-2020

DOI: $10.18196 / m l s . v 1 i 3.9495$

\begin{abstract}
Abstrak
Penelitian ini bertujuan untuk mengetahui upaya pasien BPJS Kesehatan dalam mendapatkan perlidungan hukum dan faktor penghambat maupun pendukung dalam perlindungan hukum bagi pasien BPJS Kesehatan. Penelitian ini menggunakan pendekatan empiris (yuridis sosiologis) menggunakan sumber data dan bahan hukum dalam sumber data terbagi menjadi dua bagian yaitu data primer dan sekunder sedangkan bahan hukum terbagi tiga bagian yaitu bahan hukum primer,
\end{abstract} sekunder dan tersier yang dimana bagian-bagiannya sangat penting untuk menjadi dasar penulisan karya ilmiah ini. Penelitian ini menggunakan responden dan narasumber untuk menguatkan dalil-dalil penulisan penelitian ini mengambil data yang dilaksanakan di Rumah Sakit PKU Muhammadiyah Yogyakarta, Rumah Sakit DKT Dr. Soetarto Yogyakarta, kantor BPJS Kesehatan Yogyakarta dan kantor Dinas Kesehatan Kota Yogyakarta. Untuk mencapai tujuan tersebut penulis menggunakan teknik pengumpulan data berupa wawancara serta meminta data - data kepada pihak yang terkait. Penelitian yang digunakan adalah penelitian kualitatif yaitu penelitian yang dilakukan untuk mendapatkan data-data sekunder dan bahanbahan yang berhubungan dengan penelitian yang diperoleh dari berbagai sumber. Hasil penelitian ini mendapatkan tiga rumusan masalah yaitu Upaya yang dapat dilakukan pasien pengguna BPJS Kesehatan, Faktor pendukung dan penghambat dalam mendapatkan perlindungan hukum bagi pasien BPJS Kesehatan.

Kata kunci: BPJS kesehatan; kelas rumah; sakit rujukan berjenjang

\section{Pendahuluan}

Kesehatan merupakan faktor utama bagi setiap individu untuk melangsungkan kehidupan dan kesehatan merupakan hak asasi manusia (HAM). Hal ini dimuat pada Pasal 25 ayat (1) Deklarasi Hak Asasi Manusia (HAM) Perserikatan Bangsa-Bangsa (PBB) yang menyatakan, "Setiap orang berhak atas derajat hidup yang memadai untuk kesehatan dan kesejahteraan dirinya dan keluarganya termasuk hak atas pangan, pakaian, perumahan dan perawatan kesehatan serta pelayanan sosial yang diperlukan dan berhak atas jaminan pada saat menganggur, menderita sakit, cacat, menjadi janda/duda, mencapai usia lanjut atau keadaan lainnya yang mengakibatkan kekurangan nafkah, yang berada diluar kekuasaannya". ${ }^{1}$

Diamanatkan pula dalam Undang-Undang Dasar 1945 bahwa kesehatan adalah hak asasi manusia, hal tersebut dimuat pada Pasal 28H ayat (1) dan ayat (3). Pada Pasal

\footnotetext{
${ }^{1}$ Pasal 25 ayat (1) Deklarasi Hak Asasi Manusia ( HAM )
} 
28H ayat (1) dinyatakan bahwa, "Setiap orang berhak hidup sejahtera dari lahir dan batin, bertempat tinggal dan mendapatkan lingkungan hidup yag baik dan sehat serta berhak memperoleh pelayanan kesehatan".Pada Pasal 28H ayat (3) dinyatakan bahwa, "Setiap orang berhak atas jaminan sosial yang memungkinkan pengembangan dirinya secara utuh sebagai manusia yang bermanfaat". ${ }^{2}$ Selanjutnya, pada Pasal 34 ayat 3 dinyatakan bahwa, "Negara bertanggung jawab atas penyediaan fasilitas pelayanan umum yang layak". Hal ini menunjukkan bahwa pemerintah berkewajiban memelihara dan memberikan fasilitas serta pelayanan yang layak bagi setiap individu (masyarakat) pada aspek kesehatan. ${ }^{3}$

Berdasarkan Undang-Undang Nomor 36 Tahun 2009 tentang Kesehatan meyebutkan bahwa kesehatan adalah keadaan sejahtera dari badan, jiwa, dan sosial yang memungkinkan setiap orang hidup produktif secara sosial dan ekonomis. Dengan demikian, kesehatan selain sebagai hak asasi manusia, kesehatan juga merupakan suatu investasi. ${ }^{4}$ Karena kesehatan adalah hak dan investasi, setiap warga negara berhak atas kesehatannya termasuk masyarakat miskin, untuk itu diperlukan suatu sistem yang mengatur pelaksanaan bagi upaya pemenuhan hak warga negara untuk tetap hidup sehat. $^{5}$

Kualitas kesehatan masyarakat Indonesia masih tergolong rendah, hal ini disebabkan oleh banyak faktor pula. Faktor-faktor tersebut dapat berupa kurangnya kesadaran dari masyarakat akan kesehatannya, ketidakmampuan dalam mendapatkan pelayanan kesehatan karena biaya yang mahal maupun pelayanan yang tidak memadai. Dengan kualitas kesehatan masyarakat Indonesia yang masih tergolong rendah dapat berpengaruh pada kerugian ekonomi yang besar bagi negara, dan setiap upaya peningkatan kualitas kesehatan masyarakat juga berarti investasi bagi pembangunan negara, serta setiap upaya pembangunan harus dilandasi dengan wawasan kesehatan dalam arti pembangunan nasional harus memperhatikan kesehatan masyarakat dan merupakan tanggung jawab semua pihak baik pemerintah maupun masyarakat. ${ }^{6}$

Upaya pemerintah dalam meningkatkan kualitas kesehatan masyarakat Indonesia yaitu dalah satunya dengan cara diterbitkannya Undang-Undang Nomor 40 Tahun 2004 tentang Sistem Jaminan Sosial Nasional (SJSN). Dengan diterbitkannya UndangUndang ini berarti jaminan sosial menjadi wajib termasuk jaminan kesehatan yang diperoleh dengan adanya penyelenggara jaminan sosial.

Kemudian pemerintah membentuk Undang-Undang Republik Indonesia Nomor 24 Tahun 2011 tentang Badan Penyelenggara Jaminan Sosial Kesehatan (BPJS

\footnotetext{
${ }^{2}$ Pasal 28 H Ayat (1) dan Ayat (3) Undang-Undang Dasar Negara Republik Indonesia 1945

${ }^{3}$ Pasal 34 ayat (3) Undang-Undang Dasar Negara Republik Indonesia 1945

${ }^{4}$ Muhammad Sadi,S.HI.,M.H, 2015, Etika dan Hukum Kesehatan ( Teori dan Aplikasinya di Indonesia, Edisi Pertama ), Jakarta, Kencana Prenadamedia Group, hlm. 7.

${ }^{5}$ Ibid, hlm. 13.

${ }^{6}$ Ibid, hlm. 14.
} 
Kesehatan). ${ }^{7}$ Lalu pada tanggal 31 Desember 2013 meresmikan program Badan Penyelenggara Jaminan Sosial Kesehatan (BPJS Kesehatan) sebagai pengganti Asuransi Kesehatan Indonesia (ASKES) yang telah beroperasi dibawah PT. ASKES (Persero) dan BPJS Ketenagakerjaan (Pengganti JAMSOSTEK) yang bertujuan menyelenggarakan jaminan pemeliharaan kesehatan bagi seluruh rakyat Indonesia. ${ }^{8}$ Dibentuknya BPJS Kesehatan diharapkan agar seluruh masyarakat Indonesia dapat mendapatkan pelayanan kesehatan dengan baik dan secara menyeluruh.

Namun, walau banyak manfaat yang didapat dari adanya BPJS Kesehatan masih banyak kendala yang dialami. Apalagi sejak 22 September 2018 lalu, BPJS Kesehatan mulai memberlakukan aturan baru yakni Peraturan Direktur Jaminan Pelayanan Kesehatan Nomor 4 Tahun 2018 mengenai rujukan berjenjang berdasarkan kebutuhan medis. Dengan adanya aturan tersebut membuat masyarakat harus dirujuk ke rumah sakit tipe $\mathrm{D}$ dahulu sebelum ke rumah sakit tipe $\mathrm{C}$, B dan A untuk berobat. ${ }^{9}$

Adanya aturan baru mengenai sistem rujukan berjenjang tersebut justru lebih mempersulit pasien sebagai pengguna BPJS Kesehatan dan tidak efisien. Untuk berobat ke rumah sakit saja harus melalui proses yang panjang dan lama.

Pada sistem rujukan berjenjang, pasien yang membutuhkan pelayanan kesehatan di rumah sakit tipe A butuh waktu setidaknya hingga 5 hari. Mulai dari puskesmas ke tipe D membutuhkan waktu 1 hari, ke tipe $\mathrm{C}$, lalu tipe $\mathrm{B}$ dan rumah sakit tipe A. Apalagi jika dalam satu kota rumah sakit tipe $\mathrm{C}$ dan $\mathrm{D}$ penuh, tapi tidak bisa langsung mengakses ke rumah sakit tipe B. Akibatnya pasien BPJS Kesehatan harus mencari tipe rumah sakit tipe $\mathrm{D}$ dan tipe $\mathrm{C}$ di kabupaten lain. ${ }^{10}$

Hal ini menunujukkan banyak kerugian yang dialami oleh pasien pengguna BPJS, seperti :

1. BPJS menjadi tidak efisien. Yang seharusnya adanya sistem rujukan ini untuk mempermudah pasien mendapatkan pelayanan kesehatan, pada kenyataannya malah mempersulit pasien;

2. Pasien pengguna BPJS pun harus mengeluarkan uang dan waktu yang tidak sedikit untuk mendapatkan pelayanan kesehatan; dan

\footnotetext{
${ }^{7}$ Muhammad Sadi,S.HI.,M.H, Op.Cit, hlm. 16

${ }^{8}$ Rizki Imam Hidayat, Achmad Busro, Dewi Hendrawati, 2016, Wanprestasi dalam Pelaksanaan Jaminan Sosial yang Diselenggarakan oleh BPJS di Rumah Sakit Umum Daerah (Studi Kasus di RSUD Cibonong), Vol. 05, No. 03

${ }^{9}$ Shevinna Putti Anggraeni. Dampak Besar Sistem Baru Rujukan BPJS Berjenjang, Mempersulit Berbagai PIhak. 3 Oktober 2018 (http://nakita.grid.id/amp/02949309/dampak-besar-sistem-baru-rujukan-bpjsberjenjang-mempersulit-berbagai-pihak, diakses 22 November pukul 10.25 WIB)

${ }^{10}$ Harian Merapi, Tak Efisien dan Memberatkan Pasien - Rujukan Berjenjang BPJS Kesehatan Didesak Ditinjau Ulang, 10 Oktober 2018 (https://www.harianmerapi.com/news/2018/10/10/37287/tak-efisiendan-memberatkan-pasien-rujukan-berjenjang-bpjs-kesehatan-didesak-ditinjau-ulang, diakses pada 22 November 2018, pukul 11.00 WIB)
} 
3. Tidak maksimalnya pelayanan kesehatan. Terjadi perlambatan pelayanan kesehatan di karenakan terbatasnya tenaga dan fasilitas di rumah sakit tipe D serta belum meratanya tipe rumah sakit yang ada di kota Yogyakarta.

Uraian di atas menunjukkan maksud penelitian ini dilaksanakan untuk mengetahui perlindungan bagi pasien BPJS terkait dampak adanya aturan baru mengenai sistem rujukan berjenjang dan faktor serta upaya-upaya yang dapat ditempuh pasien apabila haknya tidak terpenuhi bagi pasien BPJS khususnya di kota Yogyakarta.

\section{Metode}

Penelitian ini merupakan penelitian yuridis empiris. Penelitian yuridis (hukum dilihat sebagai norma atau das sollen), karena dalam membahas permasalahan penelitian ini menggunakan bahan-bahan hukum (baik bahan hukum primer maupun bahan hukum sekunder). Penelitian empiris (hukum sebagai kenyataan sosial atau das sein), karena dalam penelitian ini digunakan data primer yang diperoleh dari lapangan.

\section{Hasil dan Pembahasan}

Salah satu jenis program jaminan sosial menurut Pasal 18 Undang-Undang Nomor 40 Tahun 2004 tentang Sistem Jaminan Sosial Nasioanl pada dasarnya terbagi menjadi 2 yaitu jaminan kesehatan dan jaminan ketenagakerjaan. Selanjutnya dibentuk sebuah badan hukum berdasarkan prinsip penyelenggaraan Sistem Jaminan Sosial Nasional untuk mewujudkan jaminan sosial yang bermanfaat bagi kepentingan masyarakat melalui Undang-Undang Nomor 24 Tahun 2011 tentang Badan Penyelenggara Jaminan Sosial (BPJS), dalam penelitian ini akan membahas mengenai BPJS Kesehatan.

Berpedoman pada Pasal 19 ayat (1) Undang-Undang Nomor 40 Tahun 2004 tentang Sistem Jaminan Sosial Nasional menyatakan bahwa jaminan kesehatan diselenggarakan berdasarkan prinsip asuransi sosial dan prinsip ekuitas. Pada bagian penjelasan, prinsip asuransi sosial meliputi; kegotongroyongan antara yang kaya dan miskin, yang sehat dan sakit, yang tua dan muda, dan yang berisiko tinggi dan rendah; kepersertaan yang bersifat wajib dan tidak selektif; iuran berdasarkan persentase upah/penghasilan; dan bersifat nirlaba. Sedangkan prinsip ekuitas merupakan kesamaan dalam memperoleh pelayanan sesuai dengan kebutuhan medisnya yang tidak terikat dengan besaran iuran yang telah dibayarkannya.

Apabila dikaitkan dengan prinsip penyelenggaraan Sistem Jaminan Sosial Nasional menurut Pasal 4 Undang-Undang Nomor 40 Tahun 2004 tentang Sistem Jaminan Sosial Nasional yaitu prinsip kegotongroyongan dan prinsip nirlaba maka telah bersesuaian dengan prinsip asuransi sosial. Bahkan pada bagian penjelasan umum telah ditegaskan terkait mekanisme gotong royong dalam rangka mewujudkan keadilan sosial bagi seluruh rakyat Indonesia antara lain: 
1. Peserta yang mampu kepada peserta yang kurang mampu dalam bentuk kepersertaan wajib bagi seluruh rakyat;

2. Peserta yang berisiko rendah membantu yang berisiko tinggi;

3. Peserta yang sehat membantu yang sakit.

Selanjutnya sehubungan dengan prinsip ekuitas disebutkan bahwa pelayanan kesehatan bagi peserta yang akan diperoleh disesuaikan dengan kebutuhan medis dan bukan berdasarkan seberapa besar iuran yang telah dibayarkan. Pemenuhan terhadap prinsip ekuitas kemudian diterapkan dalam Pasal 42 Undang-Undang Nomor 44 Tahun 2009 tentang Rumah Sakit yang mengatur lebih lanjut tentang sistem rujukan penyelenggaraan kesehatan secara timbal balik baik vertikal maupun horizontal, maupun struktural dan fungsional terhadap kasus penyakit atau masalah penyakit atau permasalahan kesehatan.

Ketentuan mengenai sistem rujukan tersebut kemudian diatur lebih lanjut dalam Peraturan Menteri Kesehatan Nomor 001 Tahun 2012 tentang Sistem Rujukan Pelayanan Kesehatan Perorangan, melalui Pasal 2 diatur pembagian 3 tingkatan atau berjenjang pelayanan kesehatan perorangan, yaitu:

1. Pelayanan kesehatan tingkat pertama

Pelayanan kesehatan tingkat pertama merupakan pelayanan kesehatan tingkat dasar yang diberikan di puskesmas, puskesmas perawatan, tempat praktik perorangan, klinik pratama, klinik umum di balai/lembaga pelayanan kesehatan, dan rumah sakit pratama oleh dokter dan dokter gigi. Dalam keadaan tertentu, bidan atau perawat dapat memberikan pelayanan kesehatan tingkat pertama sesuai dengan ketentuan perundangundangan.

2. Pelayanan kesehatan tingkat kedua

Pelayanan kesehatan tingkat kedua merupakan pelayanan kesehatan spesialistik yang dilakukan oleh dokter spesialis atau dokter gigi spesialis dengan menggunakan pengetahuan dan teknologi kesehatan spesialistik.

3. Pelayanan kesehatan tingkat ketiga

Pelayanan kesehatan tingkat ketiga merupakan pelayanan kesehatan sub spesialistik yang dilakukan oleh dokter sub spesialis atau dokter gigi sub spesialis dengan menggunakan pengetahuan dan teknologi sub spesialistik.

Perlu dipahami terlebih dahulu, mekanisme sistem rujukan dapat dilakukan secara vertikal dan horizontal serta harus mendapatkan persetujuan dari pasien dan/atau keluarganya sebagaimana diatur dalam Pasal 7 sampai dengan Pasal 17 Peraturan Menteri Kesehatan Nomor 001 Tahun 2012 tentang Sistem Rujukan Pelayanan Kesehatan Perorangan. 
Adapun hal tersebut sehubungan pengecualian dari sistem rujukan berjenjang dapat dilakukan dalam kondisi sebagaimana dimaksud dalam Pasal 4 ayat (5) Peraturan Menteri Kesehatan Nomor 001 Tahun 2012 tentang Sistem Rujukan Pelayanan Kesehatan Perorangan:

1. Terjadi keadaan gawat darurat;

2. Terjadi bencana;

3. Adanya kekhususan permasalahan kesehatan pasien;

4. Pertimbangan geografis; dan

5. Pertimbangan ketersediaan fasilitas.

Pemberlakuan peraturan sistem rujukan berjenjang ini memberikan dampak positif bagi rumah sakit di Yogyakarta sebagaimana keterangan dalam wawancara dengan BPJS Yogyakarta yang menyatakan,

"Sehingga seringkali dahulu terjadi penumpukan pasien di suatu faskes, yang pada akhirnya pasien tersebutpun mengeluh karena antrian yang panjang tersebut."

Pernyataan serupa juga dikeluarkan oleh Dinas Kesehatan Yogyakarta yang menyatakan,

"Seperti lebih mudahnya peserta/pasien mengakses pelayanan kesehatan dan tidak membebankan suatu wilayah atau rumah sakit karena adanya penumpukan pasien.Serta rumah sakit lainnya akhirnya ada pasiennya, sebelum adanya sistem ini rumah sakit tipe D maupun C sepi pasien."

Hal yang sama juga ditegaskan oleh pihak Rumah Sakit PKU Muhammadiyah Yogyakarta yang bertipe B bahwa,

"Dari segi rumah sakit sisi positifnya rumah sakit akan bekerja sesuai kompetensinya. Apapun atau pasien yang masuk ke rumah sakit ini sudah tersaring terlebih dahulu dari rumah sakit yang adalah sistem berjenjang tersebut dan sampai pada rumah sakit kami yang memang itu kompetensi dari rumah sakit kami. Jika memang penyakitnya masih bisa ditangani oleh rumah sakit tipenya dibawah kami maka pasien tersebut akan ditangani oleh rumah sakit tersebut. Tidak seperti dahulu yang belum ada sistem rujukan berjenjang tersebut, semua pasien BPJS dapat masuk ke rumah sakit ini untuk mendapatkan pelayanan, sehingga berdampak dari pelayanan banyak dan panjang. Selain itu dengan adanya sistem rujukan berjenjang ini antrian pasien menjadi lebih cepat, penanganan pasien berdasarkan komptensinya dan jika pasien tersebut memang harus berobat ke subspesialis maka dari rujukan berjenjang tersebut pasien langsung dapat ditangani oleh subspesialis." 
Dampak positif lainnya juga dirasakan oleh Rumah Sakit DKT Dr. Soetarto Yogyakarta yang bertipe $\mathrm{C}$ menyatakan bahwa,

"Dengan adanya rujukan berjenjang ini menurut saya menjadi lebih bagus, jadi rumah sakit memberikan pelayanan sesuai dengan kompetensi rumah sakit ini. Jadi kalau pasien tersebut memang kompetensinya di rumah sakit tipe ini cukup diselesaikan di tipe ini dan kalau penyakit pasien butuh level diatas rumah sakit ini maka harus di rujuk ke rumah sakit tersebut. Menurut saya sama-sama menguntungkan bagi pasien maupun rumah sakit."

Berbeda dengan yang dirasakan oleh pasien pengguna BPJS Kesehatan, dalam penelitian ini dilakukan wawancara dengan 3 pasien pengguna BPJS Kesehatan sebagai sampel, berikut hasil wawancaranya.

1. Suharni, seorang ibu rumah tangga dengan Nomor BPJS 0000656214928 menuturkan:

"Sistem rujukan tersebut saya rasa kurang tepat, seharusnya sistem pengklasifikasian rumah sakit disesuaikan dengan iuran yang kita bayarkan untuk pelayanan BPJS tersebut.Seharusnya dalam klasifikasi rumah sakit pun harus disesuaikan dari kelas iuran yang sudah dibayarkan."

2. Irmas Juniawan, seorang karyawan swasta dengan Nomor BPJS 0000656215266 mengungkapkan:

"Menurut saya hal itu melelahkan, membutuhkan waktu yang banyak.Intinya terlalu ribet.Saya harus melalui rumah sakit yang tipenya di bawah RS PKU Muhammadiyah baru bisa di rujuk ke rumah sakit PKU.Ya seharusnya jangan ribet-ribet.Tah kita menggunakan BPJS juga membayar iuran perbulan dan tepat waktu setiap bulannya.Kalau memang BPJS tidak dapat meng-cover seharusnya pasien diberi pilihan untuk membayar biaya tambahan saja daripada harus ribet-ribet seperti itu."

Berdasarkan kedua keterangan peserta BPJS Kesehatan di atas menunjukkan bahwa pemberlakuan sistem rujukan berjenjang dinilai mempersulit peserta sebab harus melalui fasilitas kesehatan tingkat pertama atau tingkat bawah terlebih dahulu baru kemudian dilakukan rujukan ke tingkat lanjutan atau tingkat lebih tinggi. Peserta beranggapan bahwa seharusnya klasifikasi rumah sakit disesuaikan dengan iuran kelas yang dibayarkan atau diberikan pilihan untuk membayar tambahan biaya supaya mendapatkan fasilitas kesehatan yang diinginkan peserta.

3. Martoyo, seorang karyawan swasta dengan Nomor BPJS 0000656214219 menuturkan:

"Saya tidak tahu soalnya dari klinik saya langsung di rujuk ke rumah sakit ludira husada.Saya hanya bingung kenapa saya langsung di rujuk ke rumah sakit tersebut, padahal ada rumah sakit seperti Panti Rapih yang lebih bagus dan jaraknya lebih dekat dari rumah saya." 
Meninjau ketiga keterangan hasil wawancara ketiga peserta BPJS Kesehatan di atas dikerucutkan menjadi 4 permasalahan atas pemberlakuan sistem rujukan berjenjang. Keempat permasalahan tersebut yaitu ketidaktahuan peserta terhadap sistem rujukan berjenjang, keluhan atas klasifikasi rumah sakit tidak berdasarkan iuran BPJS Kesehatan, mekanisme sistem rujukan berjenjang dan biaya tambahan, dan rujukan rumah sakit yang lebih jauh. Lebih lanjut analisa atas permasalahan akan dijelaskan sebagai berikut:

1. Ketidaktahuan peserta terhadap sistem rujukan berjenjang

Persoalan ini berkaitan dengan akses keterbukaan informasi tentang BPJS Kesehatan terhadap masyarakat. Prinsip yang berlaku adalah prinsip keterbukaan sebagaimana tercantum dalam Pasal 4 huruf c Undang-Undang Nomor 40 Tahun 2004 tentang SJSN juncto Undang-Undang Nomor 24 Tahun 2011 tentang BPJS yang menyatakan, "Prinsip keterbukaan dalam ketentuan ini adalah prinsip mempermudah akses informasi yang lengkap, benar, dan jelas bagi setiap peserta."

Sehubungan dengan prinsip keterbukaan maka pemerintah dalam hal ini wajib menerapkan prinsip tersebut melalui pihak-pihak yang berkaitan dengan pelaksanaan BPJS Kesehatan. Atas hal tersebut, peneliti menanyakan terkait akses informasi tentang BPJS Kesehatan kepada Dinas Kesehatan Yogyakarta menjelaskan bahwa,

"Sosialisasi selalu dilakukan baik dari pihak bpjs, dinas kesehatan, puskesmas, maupun media massa. Hanya terkadang masyarakat sendiri yang tidak mau menyerap informasi tersebut. Karena masyarakat akan menyerap informasi tersebut hanya ketika memang ia membutuhkan informasi tersebut. Selain itu karena perbedaan latar belakang setiap masyarakat sehingga mempengaruhi daya serap informasi tersebut."

Terkait kurangnya informasi yang diterima peserta, BPJS Yogyakarta juga menambahkan peserta yang merasa dirugikan atas pemberlakuan sistem ini akan dilakukan edukasi mengenai regulasi sistem rujukan berjenjang oleh staff Pusat Pelayanan Informasi Penanganan Pengaduan (PPIP) yang berasal dari rumah sakit dan BPJS Kesehatan yang ditugaskan pada setiap rumah sakit yang bekerjasama dengan BPJS Kesehatan. BPJS Kesehatan Kota Yogyakarta pun menanggapi terkait penyebaran informasi bahwa,

"BPJS sudah memasuki tahun ke-5, untuk segmen mandiri mekanisme sosialisasi dibagian kepesertaan maupun informasi \& publik akan diiberikan informasi melalui seperti media sosial (twitter, facebook, televisi, radio, dll) bahkan untuk masyarakat bisa mendapatkan informasi tersebut di puskesmas maupun organisasi yang ada dalam masyarakat (PKK). Seharusnya masyarakat sudah terpapar dengan sendirinya dan sudah menyeluruh apalagi di wilayah kota Yogyakarta itu sendiri. Di kota Yogyakarta-pun dibantu oleh pemerintah daerah mengenai kepesertaan bpjs ini, dengan cara mendata masyarakatnya yang sudah maupun belum menjadi peserta BPJS. Nanti ketika masyarakat tersebut termasuk masyarakat yang tidak mampu akan didaftarkan oleh pemerintah daerah dan pembayarannya menggunakan APBD." 
2. Keluhan atas klasifikasi rumah sakit tidak berdasarkan iuran BPJS Kesehatan

Sebenarnya terhadap keluhan klasifikasi rumah sakit telah diatur secara tegas melalui prinsip ekuitas yang merupakan salah satu prinsip penyelenggaraan jaminan kesehatan secara nasional menurut Pasal 19 ayat (1) Undang-Undang Nomor 40 Tahun 2004 tentang Sistem Jaminan Sosial Nasional. Prinsip ekuitas menegaskan, pelayanan kesehatan bagi peserta yang akan diperoleh disesuaikan dengan kebutuhan medis dan bukan berdasarkan seberapa besar iuran yang telah dibayarkan. Prinsip ekuitas kemudian diterapkan sebagai dasar klasifikasi rumah sakit berdasarkan Pasal 24 Undang-Undang Nomor 44 Tahun 2009 tentang Rumah Sakit menurut fasilitas dan kemampuan pelayanan rumah sakit.

Selanjutnya Pasal 42 Undang-Undang Nomor 44 Tahun 2009 tentang Rumah Sakit yang mengatur lebih lanjut tentang sistem rujukan penyelenggaraan kesehatan sesuai dengan kasus penyakit atau masalah penyakit atau permasalahan kesehatan. Pengaturan sistem rujukan ini kemudian diatur melalui Peraturan Menteri Kesehatan Nomor 001 Tahun 2012 tentang Sistem Rujukan Pelayanan Kesehatan Perorangan.

3. Mekanisme sistem rujukan berjenjang dan biaya tambahan

Menurut keterangan dari pihak Dinas Kesehatan Kota Yogyakarta dan BPJS Kesehatan Kota Yogyakarta mengatakan mekanisme sistem rujukan berjenjang yang mengharuskan peserta untuk diperiksa pada fasilitas kesehatan tingkat pertama atau primer terlebih dahulu kemudian baru bisa dirujuk ke fasilitas kesehatan rujukan tingkat lanjutan telah terdapat dasar hukum yang mengatur yaitu :

a) Undang-Undang Nomor 44 Tahun 2009 tentang Rumah Sakit;

b) Peraturan Menteri Kesehatan Nomor 001 Tahun 2012 tentang Sistem Rujukan Pelayanan Kesehatan Perorangan;

c) Peraturan Presiden Nomor 82 Tahun 2018 tentang Jaminan Kesehatan.

Latar belakang pembentukan sistem rujukan berjenjang ini adalah untuk membentuk jejaring dalam rangka peningkatan pelayanan kesehatan secara optimal seperti yang diungkapkan BPJS Yogyakarta bahwa,

"Sebelum adanya sistem ini semua pasien menumpuk di suatu faskes tanpa ada mekanisme pengaturan, jadi pasien bisa seenaknya mau berobat di faskes tingkat pertama maupun yang lain padahal di kota yogyakarta sendiri ada kurang lebih 62 faskes bpjs kesehatan, yang diantaranya kurang lebih ada 12 rumah sakit tipe D, C, B dan A. Sehingga seringkali dahulu terjadi penumpukan pasien di suatu faskes, yang pada akhirnya pasien tersebutpun mengeluh karena antrian yang panjang tersebut. Jika mengacu pada regulasi ini seharusnya menjadi rata, karena rumah sakit tipe D maupun C cukup banyak di kota Yogyakarta ini. Jadi adanya regulasi itu ditetapkan memang untuk agar penyelenggaraan terhadap sistem tersebut bisa lebih optimal.Jika tidak ada regulasi tersebut penyelenggaraan pasti menjadi tidak optimal." 
Persoalan berikutnya mengenai biaya tambahan, pihak BPJS Kesehatan Kota Yogyakarta, mengungkapkan:

"Sebernarnya terkait mengenai biaya tambahan bisa dilihat pada Peraturan Presiden Nomor 82 Tahun 2018 tentang Jaminan kesehatan yang telah memberikan keleluasaan bagi peserta BPJS Kesehatan serta dalam Peraturan Menteri Kesehatan Nomor 28 Tahun 2014 tentang Pedoman Pelaksanaan Program Jaminan Kesehatan Nasional (PPPKJN)"

Pada Peraturan Presiden Nomor 82 Tahun 2018 tentang Jaminan Kesehatan Pasal 51 memang benar adanya telah memberikan keleluasaan bagi peserta BPJS Kesehatan yang ingin meningkatkan perawatan yang lebih tinggi dari haknya termasuk rawat jalan eksekutif dengan mengikuti asuransi kesehatan tambahan atau membayar selisih antara biaya yang telah dijamin oleh BPJS Kesehatan dengan biaya yang harus dibayar akibat peningkatan pelayanan. Selisih tersebut dapat dibayar oleh peserta yang bersangkutan, pemberi kerja, atau asuransi kesehatan tambahan.

Tetapi terdapat pengecualian ketentuan ini bagi PBI Jaminan Kesehatan, peserta yang didaftarkan oleh pemerintah daerah, dan peserta PPU yang mengalami PHK dan anggota keluarganya. Hal ini berlaku dalam ranah fasilitas pelayanan kesehatan pada tingkat yang telah disesuaikan dengan kasus dan kompetensi fasilitas kesehatan. Namun apabila peserta atas permintaan sendiri untuk dirujuk ke pelayanan kesehatan lain yang tidak sesuai maka pelayanan kesehatan tersebut tidak lagi dijamin oleh BPJS Kesehatan.

Selain itu, pada Peraturan Menteri Kesehatan Nomor 28 Tahun 2014 tentang Pedoman Pelaksanaan Program Jaminan Kesehatan Nasional bahwa pasien yang ingin meningkatkan kelas perawatan dibagi menjadi 2 jenis:

a) Sampai dengan kelas I, maka diberlakukan urun biaya selisih tarif kelas ruang perawatan yang dipilih dengan biaya yang telah dijamin;

b) Jika naik ke kelas perawatan VIP, maka diberlakukan urun biaya sebesar selisih tarif VIP lokal dengan tarif kelas perawatan yang telah dijamin.

4. Rujukan rumah sakit yang lebih jauh

Sesungguhnya dalam Pasal 6 Peraturan Menteri Kesehatan Nomor 001 Tahun 2012 tentang Sistem Rujukan Pelayanan Kesehatan Perorangan mengatur terkait rujukan seharusnya dilakukan ke fasilitas pelayanan kesehatan terdekat yang memiliki kemampuan pelayanan sesuai kebutuhan pasien dalam rangka meningkatkan aksesibilitas, pemerataan dan peningkatan efektifitas pelayanan kesehatan. Dinas Kesehatan Yogyakarta juga menanggapi bahwa,

"Lalu mengenai adanya pasien yang terlempar ke luar kabupaten, memang pada awal berjalannya sistem ini terjadi hal seperti itu. Namun seiring berjalannya waktu hal tersebut tidak terjadi lagi dan beda kasusnya jika peserta atau pasien tersebut tinggal di perbatasan. Misalnya tempat tinggal pasien berada diperbatasan antara Bantul dan kota Yogyakarta, maka akan dipilihkan rumah sakit yang jaraknya lebih dekat dengan tempat 
tinggal pasien tersebut, dan dengan syarat tipe rumah sakitnya sesuai dengan penyakit yang diderita pasien. Hal tersebut juga sudah tercantum atau sudah dijelaskan di panduan praktis sistem rujukan berjenjang yang bisa di download di website BPJS, selain itu tertuang pula di SK Gubernur.”

Adanya kontra dan keluhan dari pasien peserta BPJS Kesehatan terkait sistem rujukan berjenjang tersebut pihak pemerintah, BPJS Kesehatan dan rumah sakit yang bekerjasama dengan BPJS Kesehatan sudah melakukan antisipasi dengan cara dibuatkannya wadah bagi pasien BPJS Kesehatan. Hal ini dikemukakan pihak Dinas Kesehatan Kota Yogyakarta bahwa,

"Dinas kesehatan meberikan wadah bagi masyarakat, yakni seperti di pemerintah kota menyediakan sarana masyarakat untuk mengadukan keluhan terkait, dapat pula melalui website, lalu melalui whatsapp, sms, telepon, bisa langsung ke faskes tersebut, dan lain-lain. Dinas kesehatan disini menampung semua permasalahan-permasalahan yang dialami oleh masyarakat. Kemudian di Kota Yogyakarta sendiri juga disediakan JSS (Jogja Smart Service) yaitu semua penduduk Kota Yogyakarta dapat mengakses itu untuk menyalurkan keluhan maupun saran terkait."

Gambar 1. Flowchart (diagram alir) proses aduan keluhan

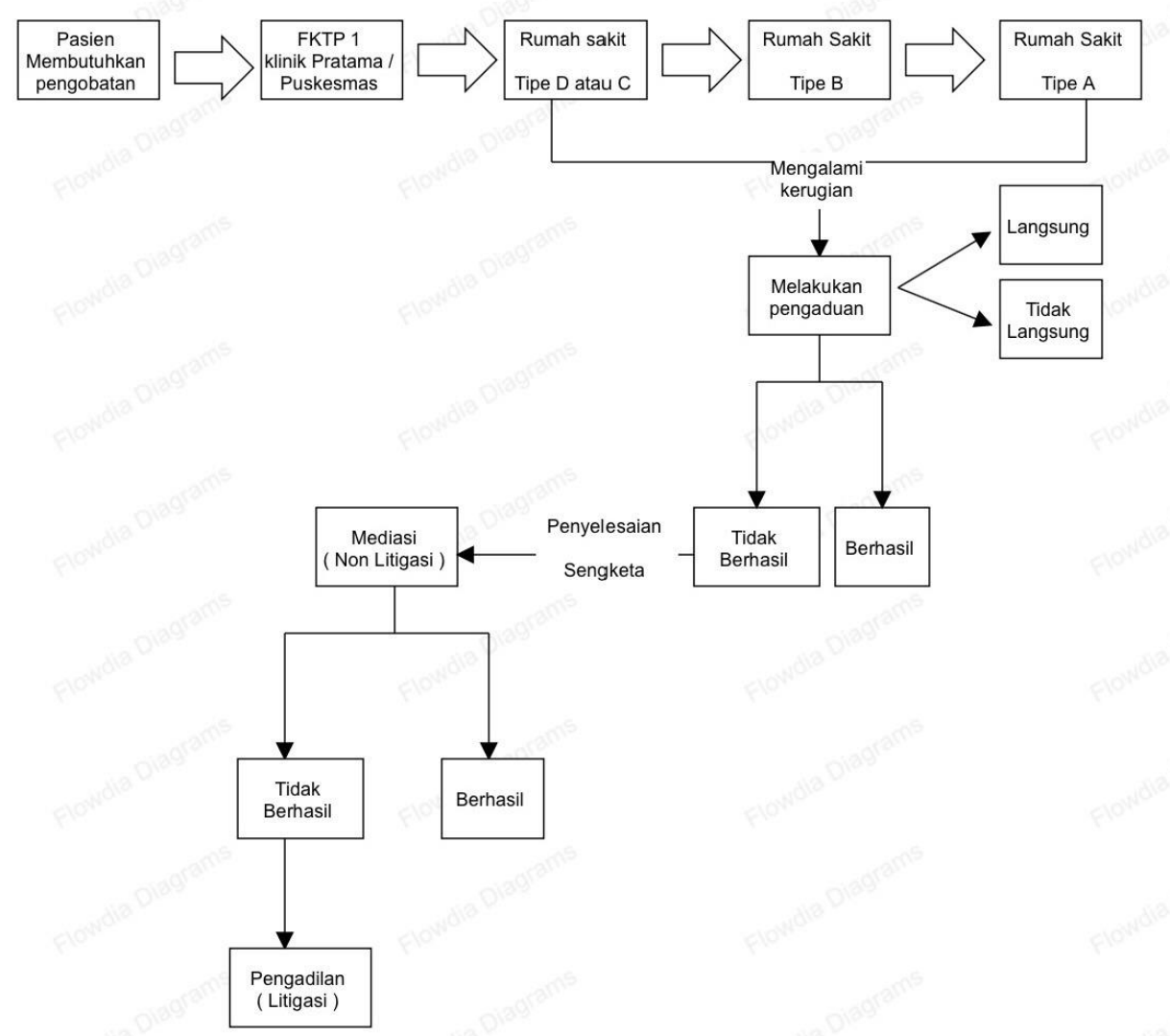

Sumber: dokumen BPJS 
Hal yang juga dikemukakan oleh pihak BPJS Kesehatan, Rumah Sakit Muhammadiyah Yogyakarta dan Rumah Sakit DKT Dr. Soetarto Yogyakarta bahwa di setiap rumah sakit maupun kantor BPJS Kesehatan diberikan tempat/wadah pengaduan bagi pasien. Jika di rumah sakit yang akan menangani adalah staff PIPP yang dimana staf tersebut ada yang berasal dari rumah sakit dan ada yang berasal dari BPJS Kesehatan yang bertugas untuk menerima aduan keluhan dari pasien dan mengedukasi pasien tersebut terkait keluhannya.

Pada flowchart (diagram alir) gambar 1 menjelaskan pada pasien BPJS Kesehatan yang mengalami kerugian dan mempunyai keluhan terkait sistem rujukan berjenjang tersebut maka dapat melakukan pengaduan di rumah sakit terkait maupun kantor BPJS terdekat. Pengaduan tersebut dapat dilakukan secara langsung maupun tidak langsung. Pengaduan secara langsung dapat berupa tatap muka langsung saat melakukan pengaduan maupun melalui media telepon ke call center maupun hotline service BPJS. Sedangkan pengaduan secara tidak langsung dapat berupa, seperti:

a. Surat menyurat; b. Sms gateway; c. Email;d. Website; dan e. Media Sosial beratas namakan BPJS Kesehatan. ${ }^{11}$

Penyelesaian sengketa akan dilakukan apabila pengaduan tersebut tidak bisa diselesaikan atau sudah lewat jangka waktu menangani pengaduan yakni 5 (lima) hari. Penyelesaian sengketa tersebut yakni melakukan mediasi (non litigasi) dengan jangka waktu maksimal 30 hari kerja. Jika penyelesaian sengketa berhasil maka hasil mediasi dibuat secara tertulis, final dan mengikat para pihaknya. Namun jika penyelesaian sengketa melalui mediasi belum dapat menyelesaikan sengketa maka dapat dilakukan melalui pengadilan (litigasi).

Gambar 2. Flowchart (diagram alir) proses penanganan keluhan pelibatan ombdsman.

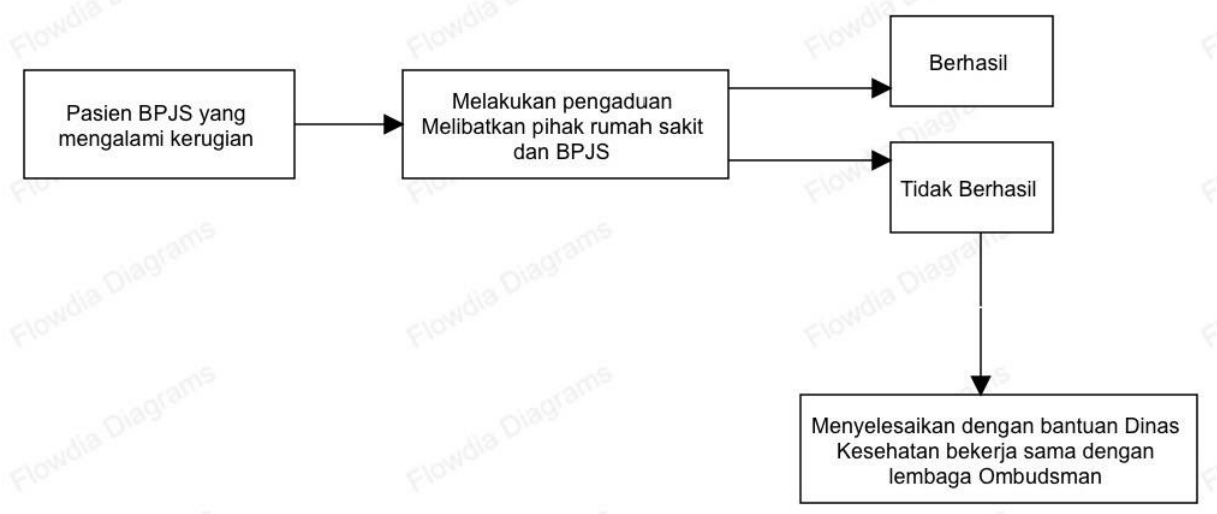

Sumber: Dokumen Dinas Kesehatan Kota Yogyakarta

\footnotetext{
${ }^{11}$ Pasal 3 ayat (5), Peraturan Badan Penyelenggara Jaminan Sosial Kesehatan Nomor 2 Tahun 2014 tentang Unit Pengendali Mutu Pelayanan Dan Penanganan Pengaduan Peserta
} 
Menurut pihak Dinas Kesehatan Kota Yogyakarta dalam penyelesaian sengketa pasien BPJS Kesehatan mengenai sistem rujukan ini, bahwa:

"Selama ini penyelesaian masalah jika tidak bisa ditangani oleh pihak rumah sakit dan BPJS Kesehatan maka akan dibantu oleh pihak Dinas Kesehatan Kota Yogyakarta. Namun penyelesaian sengketa ini tidak sampai dilakukan ke pengadilan. Pada prakteknya dapat diselesaikan hanya dengan bantuan lembaga Ombudsman. Yang dimana dinas kesehatan melibatkan lembaga Ombudsman dalam penyelesaian masalah dengan pasien mengenai masalah-masalah terkait sesuai alur gambar 2."

Gambar 3. Flowchart (diagram alir) proses penanganan keluhan pelibatan BPSK.

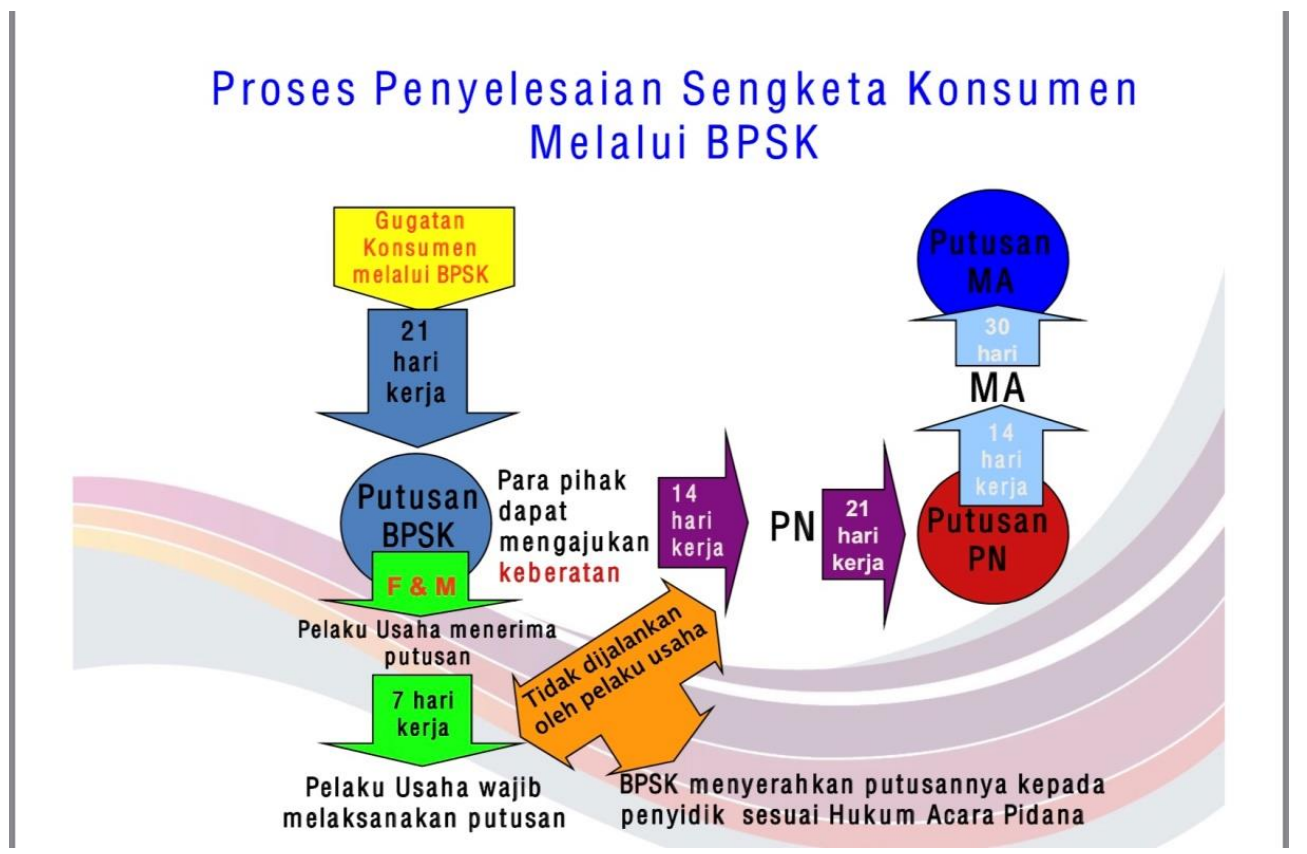

Sumber: Dokumen BPSK

Penyelesaian sengketa dalam hal ini dapat pula dilakukan melalui proses penyelesaian sengketa konsumen melalui Badan Penyelesaian Sengketa Konsumen (BPSK). Hal ini dikarenakan pasien pada sisi yang lain merupakan konsumen.

\section{Simpulan}

Upaya perlindungan hukum yang dapat dilakukan oleh pasien BPJS berupa yakni seperti: Pasien dapat melakukan pengaduan secara langsung maupu tidak langsung. Pengaduan secara langsung dapat berupa tatap muka langsung dengan pihak terkait dengan datang ke bagian pengaduan rumah sakit maupun kantor BPJS Kesehatan terdekat, maupun melalui media telepon service center atau hotline service. Dan pengaduan tidak langsung melalui surat menyurat, sms gateway, email, website dan media sosial beratas namakan BPJS Kesehatan. Dengan pihaknya rumah sakit dan BPJS Kesehatan. Namun jika pihak tersebut belum bisa menyelesaikan permasalahan tersebut maka akan diselesaikan dengan bantuan Dinas Kesehatan Kota Yogyakarta bekerjasama 
dengan lembaga Ombudsman. Selain itu, jika pasien masih belum puas atas pengaduan maupun jangka waktu penyelesaian melalui pengaduan sudah lewat, maka dapat dilakukan penyelesaian sengketa melalui mediasi (non litigasi) maupun penyelesaian melalui pengadilan (litigasi).

\section{Daftar Pustaka}

\section{Buku}

Sadi,Muhamad, 2015, Etika dan Hukum Kesehatan (Teori dan Aplikasinya di Indonesia, Edisi Pertama), Jakarta, Kencana Prenamedia Group.

Azwar, Asrul, 1996, Pengantar Administrasi Kesehatan, Jakarta, Binarupa Aksara.

\section{Jurnal}

Rizki Imam Hidayat, AchmadBusro, DewiHendrawati, 2016, Wanprestasi dalam Pelaksanaan Jaminan Sosial yang Diselenggarakan oleh BPJS di Rumah Sakit Umum Daerah (Studi Kasus di RSUD Cibonong), Diponegoro Law Journal, Vol. 05, No. 03

\section{Internet}

Shevinna Putti Anggraeni, Dampak Besar Sistem Baru Rujukan BPJS Berjenjang, Mempersulit Berbagai Pihak, $03 \quad$ Oktober 2018 (http://nakita.grid.id/amp.02949309/dampak-besar-sistem-baru-rujukan-bpjsberjenjang-mempersulit-berbagai-pihak, diakses pada 22 November 2018 pukul 10.25 WIB)

Harian Merapi, Tak Efisien dan Memberatkan Pasien - Rujukan Berjenjang BPJS Kesehatan Didesak Ditinjau Ulang, 10 Oktober 2018 (http://www.harianmerapi.com/news/2018/10/10/37287/tak-efisien-danmemberatkan-pasien-rujukan-berjenjang-bpjs-kesehatan-didesak-ditinjau-ulang, diakses pada 22 November 2018 pukul 11.00 WIB)

\section{Undang-Undang}

Deklarasi Hak Asasi Manusia (HAM)

Undang-Undang Dasar Negara Republik Indonesia Tahun 1945

Undang-Undang Nomor 44 Tahun 2009 Tentang Rumah Sakit

Undang-Undang Nomor 24 Tahun 2011 Tentang Badan Penyelenggara Jaminan Sosial (BPJS)

Peraturan Menteri Kesehatan Nomor 001 Tahun 2012 Tentang Sistem Rujukan Pelayanan Kesehatan Perorangan

Peraturan Presiden Nomor 82 Tahun 2018 Tentang Jaminan Kesehatan 